\title{
Quantitative identification of water consumption in electricity development in 2017 in China
}

\author{
HE Guohua $^{1 *}$, JIANG Shan ${ }^{1}$, ZHU Yongnan ${ }^{1}$, HE Fan $^{1}$, Li Xiaoling ${ }^{2}$, LI Haihong ${ }^{1}$ \\ ${ }^{1}$ State Key Laboratory of Simulation and Regulation of Water Cycle in River Basin, China Institute of Water Resources and Hydropower \\ Research, Beijing 100038, China \\ ${ }^{2}$ College of Civil Engineering and Architecture, Guangxi University, Nanning, Guangxi 530004, China
}

\begin{abstract}
This paper takes each province and region as the research object and 2017 as the research period, and the water consumption of power production was analyzed. The results showed that China's electricity production consumed 6.57 billion $\mathrm{m}^{3}$ of water, accounting for $2 \%$ of the total social water consumption in 2017. Thermal power is the most water-consuming power source in China, accounting for $78 \%$ of the total water consumption in the country's electric power development. Based on the calculated results, this study also puts forward relevant suggestions for realizing energy-water coordinated security.
\end{abstract}

\section{Introduction}

According to the research results of the IEA, the global water consumption in the process of energy development has reached 583 billion $\mathrm{m}^{3}$, which is the second largest user of water after agriculture, accounting for $15 \%$ of the global fresh water consumption 1. It is estimated that by 2035, water withdrawals from energy production will increase by $20 \%$ compared with 20142 . On a global scale, energy and water resources have become important constraints to each other's sustainable development. Previous studies have shown that the study of energy and water resources as a separate system is not enough to support the formulation of decision-making schemes, and it may even mislead the decision-making 3 . In the context of the substantial increase in global resource demand, only by taking energy and water resources as a research body, enhancing the coordination, rational allocation and constantly adjusting human behavior, can the green development of the region be realized 4.

In recent years, the relationship between energy and water is becoming a hot topic in the world. The academic research on this link mainly focuses on the following two aspects: first, the internal connection between energy and water in the policy, planning and changing environment; The second is to quantitatively assess the energy consumption and water consumption of the water cycle in different regions 5-7]. Due to the shortage of energy and water resources and the significant spatial difference between them, China has become a hot spot in the research on the global energy and water nexus. Many scholars have carried out quantitative research on the energy-water nexus in typical areas such as the Yellow River basin 8, Beijing 9 and the national scale 10-12. At present, China is the largest producer and consumer of energy in the world, with the proportion of energy production and consumption accounting for $18 \%$ and $23 \%$ of the global total respectively. However, China's fossil energy base is mainly distributed in the arid central and western regions, and energy development is increasingly stressed by water resources. According to the research results of Jiang Shan et al. 14, at present, China's energy and water problems are mainly faced with three challenges: 1) rapidly increasing consumption demand of energy and water; 2) the optimal selection of energy-intensive water sources and water-intensive energy sources; 3 ) the coupling and coordination of energy-water cross-sector policy making.

The quantitative identification of the relationship between energy and water is the basis of China's economic, social and ecological sustainable development. But at present, the academic circles mainly carry out research on the framework concept of this bond, and there are few quantitative researches in the whole country. Based on this, this article takes the provincial administrative region for the study of the smallest unit, choose 2017 as the current level year. The water consumption in the process of power development is quantitatively analyzed, and based on the research results, the policy suggestions for the coordinated development of energy and water in China are put forward, so as to provide references for the sustainable development of economy, resources and environment in Chi

*Corresponding author: He Guohua $($ hegh@iwh.com) 


\section{Methods and data}

\subsection{Calculation of water consumption during power production process}

The energy industry is a major water user in China. According to the energy structure of China, this study calculated the water consumption of power generation processes of six major power sources (thermal, nuclear, hydro, biomass, solar and wind). Since detailed data of water consumption of different power plants are difficult to obtain, the calculation of water consumption of electricity production mainly uses the quota method. The water consumption intensity of different power sources is shown in Table 1.

Table 1 Water consumption quota of different power sources

\begin{tabular}{|c|c|c|c|}
\hline \multicolumn{2}{|c|}{ Power source } & $\begin{array}{c}\text { Water } \\
\text { consumption } \\
\text { intensity } \\
(\mathrm{L} / \mathrm{kWh})\end{array}$ & $\begin{array}{c}\text { Data } \\
\text { sources }\end{array}$ \\
\hline \multirow{3}{*}{$\begin{array}{l}\text { Thermal } \\
\text { power }\end{array}$} & $\begin{array}{l}\text { Once-through } \\
\text { cooling }\end{array}$ & $0.38-2.31$ & \multirow{3}{*}{1617} \\
\hline & $\begin{array}{l}\text { Circulating } \\
\text { cooling (tower) }\end{array}$ & $1.10-2.60$ & \\
\hline & $\begin{array}{l}\text { Circulation } \\
\text { cooling (pond) }\end{array}$ & $1.02-3.38$ & \\
\hline \multirow{3}{*}{$\begin{array}{l}\text { Nuclear } \\
\text { power }\end{array}$} & $\begin{array}{l}\text { Once-through } \\
\text { cooling }\end{array}$ & $0.65-1.50$ & \multirow{3}{*}{1819} \\
\hline & $\begin{array}{l}\text { Circulating } \\
\text { cooling (tower) }\end{array}$ & $1.33-3.20$ & \\
\hline & $\begin{array}{l}\text { Circulation } \\
\text { cooling (pond) }\end{array}$ & $1.33-2.70$ & \\
\hline \multicolumn{2}{|l|}{ Hydropower } & 1.80 & 20 \\
\hline \multicolumn{2}{|c|}{ Biomass power generation } & $25.00-35.00$ & 21 \\
\hline \multirow{2}{*}{$\begin{array}{l}\text { Solar power } \\
\text { generation }\end{array}$} & $\begin{array}{l}\text { Photovoltaic } \\
\text { power generation }\end{array}$ & 0.02 & 22 \\
\hline & solar power & $2.80-3.30$ & 23 \\
\hline \multicolumn{2}{|l|}{ Wind power } & $0.00-0.05$ & 24 \\
\hline
\end{tabular}

\subsection{Data sources}

In this study the power generation data of different power sources come from China energy statistical yearbook 25 and compilation of statistics of China's electric power industry 26 .

\section{Results and discussion}

\subsection{Analysis of water consumption in power production process}

In 2017, China's electricity production process consumed 6.57 billion $\mathrm{m}^{3}$ of water, accounting for $2 \%$ of the total water consumption of the whole society (Figure.1). Thermal power is the most water-consuming power source in China, accounting for $78 \%$ of the total water consumption of the national power development. This is mainly due to the relatively rich coal resources in China, with coal reserves accounting for $96 \%$ of China's fossil energy reserves. At the same time, thermal power generation, as the main power production structure, accounts for $76 \%$ of China's total power generation. The main water consumption of nuclear power generation is cooling water. In 2017, China's water consumption of nuclear power was 639 million $\mathrm{m}^{3}$, accounting for $7.5 \%$ of the total water consumption for power generation. In the process of hydropower generation, the evaporation capacity of the reservoir required for each unit of energy production is taken as its water consumption. In 2017, China's total water consumption of hydropower is about 496 million $\mathrm{m}^{3}$. Considering the multiple objectives of flood control, water supply and power generation, the calculation results of this study may overestimate the water consumption of hydropower. Due to the small scale of power generation, biomass energy, solar energy and wind energy in China consume less water. In 2017, the total water consumption was only $1.71,0.12$ and 161 million $\mathrm{m}^{3}$ respectively. By comparing the water consumption intensity of different power sources, it can be seen that wind power and photovoltaic power generation are the most water-saving power products at present. The vigorous development of clean energy such as wind power and solar power is not only conducive to the ecological environment protection and climate change control in China, but also conducive to easing the contradiction between the supply and demand of water resources in China.

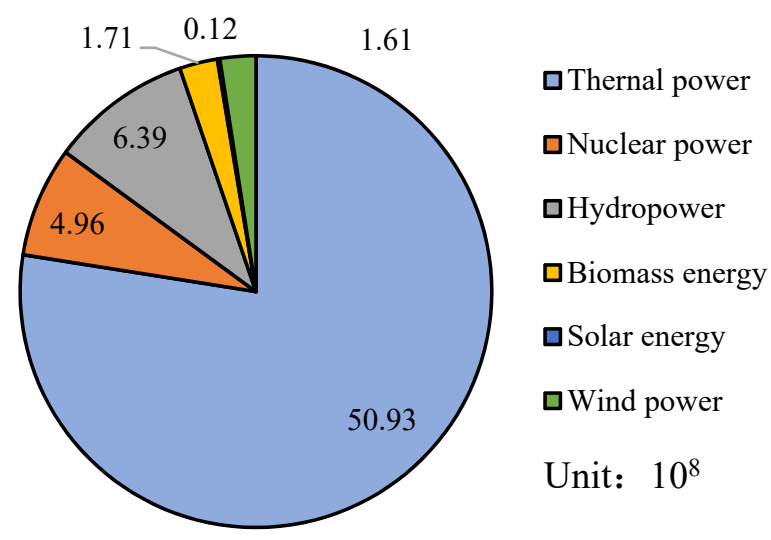

Figure.1 Water consumption for power development in China in 2017

\subsection{Spatial variation of water consumption in power production process}

The water consumption in the process of power production is affected by the local power generation, power generation technology and power structure. Figure. 2 shows the 2017 water consumption of electric power production process in the different provinces in China, among which Shandong, Jiangsu, Inner Mongolia water consumption of coal-fired power is higher. This is mainly due to large scale of thermal power generation in the region. In 2017, Shandong, Jiangsu and Inner Mongolia generated 437.8 billion $\mathrm{kWh}, 382.3$ billion $\mathrm{kWh}$ and 372.6 billion $\mathrm{kWh}$ of thermal power generation, 
accounting for $10.56 \%, 9.21 \%$ and $8.98 \%$ of China's total thermal power generation, respectively. China's nuclear power plants are mainly distributed in coastal areas. In 2017, the water consumption of nuclear power development in Guangdong, Fujian and Zhejiang accounted for $32 \%, 23 \%$ and $21 \%$ of the total water consumption of nuclear power development respectively. Southwest China is the most important hydropower

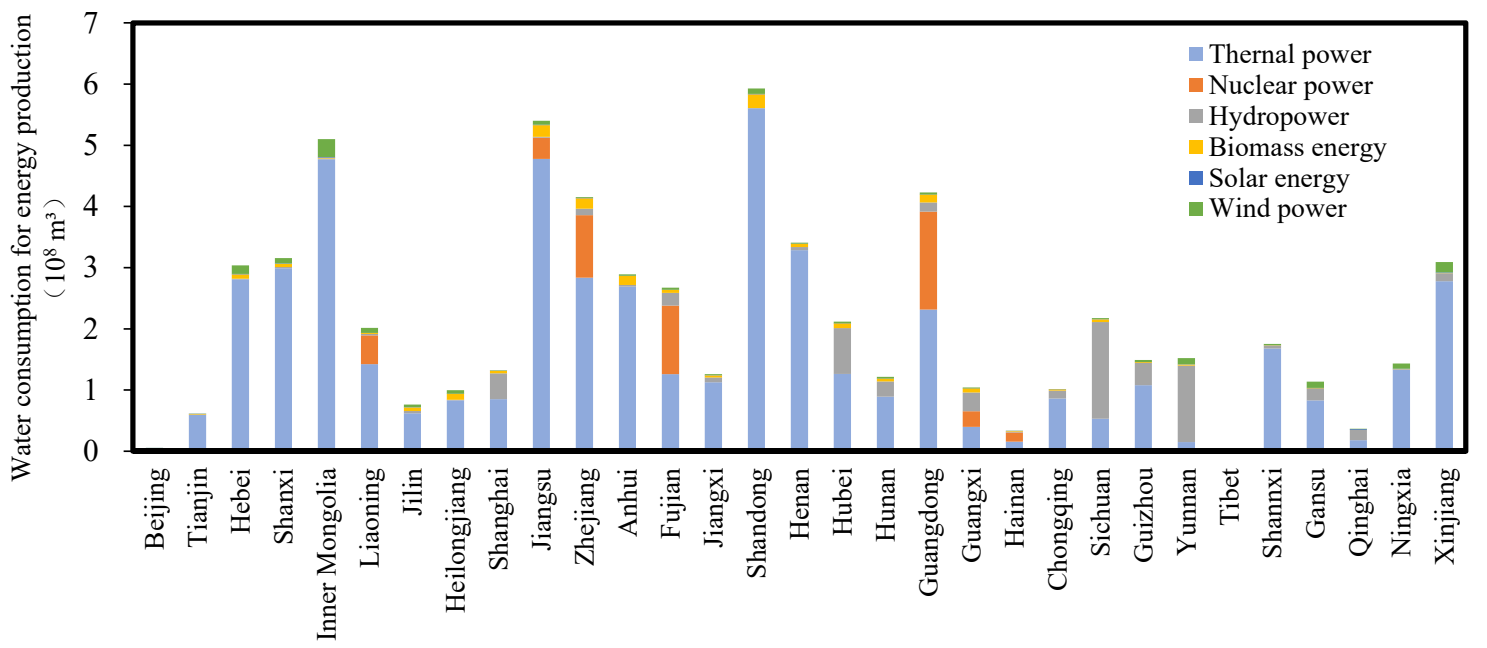

Figure.2 Water consumption for power development in different provinces in 2017

energy base in China, and its hydropower resources account for $66.7 \%$ of the national total. According to the calculation of this study, water consumption of hydropower in Sichuan province in 2017 was 158 million $\mathrm{m}^{3}$, accounting for $73 \%$ of the total water consumption of power development of the province. Water consumption of hydropower in Yunnan is 125 million $\mathrm{m}^{3}$, accounting for $82 \%$ of the province's water consumption of power development. Hydropower has become the most important power production and water consumption sector in these two provinces. Clean energy in China consumes less water. Wind power mainly consumes water in northern provinces, while biomass power mainly consumes water in Jiangsu, Zhejiang, Anhui, Shandong and Guangdong.

\section{Conclusion and suggestion}

\subsection{Conclusion}

This paper analyzes the power development water consumption of the provinces (municipalities and autonomous regions) in 2017 and draws the following conclusions.

In 2017, China's water consumption during electricity production was 6.57 billion $\mathrm{m}^{3}$, accounting for $2 \%$ of the total water consumption of the whole society. Thermal power is the most water-consuming power source in China, accounting for $78 \%$ of the total water consumption of the national power development. The water consumption of nuclear power and hydropower development is 639 and 496 million $\mathrm{m}^{3}$ respectively, while wind, solar and biomass use relatively little water. From the perspective of zoning, Shandong and Xizang are the provinces and regions with the largest and smallest water consumption for power development, respectively, with water consumption of 593 and 0.03 million $\mathrm{m}^{3}$.

\subsection{Suggestion}

Due to the uneven spatial distribution of water resources and energy resources in China, the water consumption of energy exploitation has exerted great influence on regional energy security and water security respectively. In order to realize the collaborative security of water resources and energy, this paper proposes the following three suggestions based on the research results:

(1) Northwest fossil energy base is the main energy output area in our country in the future, although at this stage the power production process in northwest China consumes less water, considering the increase in the scale of energy development and the situation of water shortage in the future, it is necessary to further study the relationship between energy and water in northwest China and improve the water resources security of northwest fossil energy base.

(2) The water consumption intensity of developing clean energy such as solar energy and wind energy is significantly lower than that of thermal power and nuclear power. The vigorous development of clean energy in China is not only conducive to reducing pollution and improving energy structure, but also conducive to the conservation and protection of water resources.

(3) The water-energy system management concept should be established based on the development characteristics and resource endowment conditions of different regions, the energy influence should be considered in the process of water resources development, and the water resources restriction should be considered in the process of energy development, so as to realize the coordinated security of water resources and energy in China. 


\section{Acknowledgments}

This work was funded by the International Science \& Technology Cooperation Program of China (2018YFE0196000), the Key consulting project of Chinese Academy of Engineering (2019-XZ-33), National Key Research and Development Program of China (2016YFC0401306); National Youth Science Foundation (51809282).

\section{References}

1. International Energy Agency. (2012) World Energy Outlook.

2. United Nations Educational, Scientific and Cultural Organization. (2014) The United Nations World Water Development Report.

3. Wang H M, Hong J, Liu G. (2019) Simulation research on different policies of regional green development under the nexus of water-energy-food. J. China Population, Resources and Environment, 29(6):74-84.

4. Wang S X. (2018) The limit and cycle of energy and mineral resources consumption growth. J. World Nonferrous Metals, 5: 254-256.

5. Okadera T, Chontanawat J, Gheewala $\mathrm{S} \mathrm{H}$, et al. (2014) Water footprint for energy production and supply in Thailand. J. Energy, 77: 477-494.

6. Li X, Liu J, Zheng C, et al. (2016) Energy for water utilization in China and policy implications for integrated planning. J. International Journal of Water Resources Development, 32(3): 477-494.

7. Gao J J. (2012) Correlation analysis of water resource utilization and power production in China. D. Tianjin: Tianjin University.

8. Xiang X Z, Jesper S, Jia S F. (2017) Will the energy industry drain the water used for agricultural irrigation in the Yellow River basin?. J. International Journal of Water Resources Development, 33(1): 69-80.

9. He G H, Zhao Y, Wang J H, et al. (2019) The effects of urban water cycle on energy consumption in Beijing, China. J. Journal of Geographical Sciences, 29(6): 959-970.

10. Xiang X Z, Jia S F. (2016) Estimation and Trend Analysis of Water Demand of Energy Industry in China. J. Journal of Natural Resources, 31(1): 114-123.

11. Xiang X Z, Jia S F. (2019) China's water-energy nexus: Assessment of water-related energy use. J. Resources, Conservation and Recycling, 144: 32-38.

12. He G H, Zhao Y, Jiang S, et al. (2019) Impact of virtual water transfer among electric sub-grids on China's water sustainable developments in 2016, 2030, and 2050. J. Journal of Cleaner Production, 229: $1546-1559$.
13. Peng S M, Wang H, Zhang X H. (2011) Research on the development demand and water resources control strategy of the middle and upper reaches of the Yellow River. J. China Water Resources, 21: 28-31.

14. Jiang S, Zhao Y, Shang Y Z, et al. (2016) Balancing Development of Thermal Power with Available Water Resources in Major Coal Bases of China. J. Water Resources and Power, 34(11): 40-43.

15. Wang J X, Rothausen S G S A, Conway D, et al. (2012) China's water-energy nexus: greenhouse-gas emissions from groundwater use for agriculture. J. Environmental Research Letters, 7(1): 14035-14044.

16. Ali B, Kumar A. (2015) Development of life cycle water-demand coefficients for coal-based power generation technologies. J. Energy conversion and management, 90: 247-260.

17. Byers E A, Hall J W, Amezaga J M. (2014) Electricity generation and cooling water use: UK pathways to 2050. J. Global Environmental Change, 25: $16-30$.

18. Jiang Q, Jin D. (2011) Problems and countermeasures in rationality analysis of water used in Binhai Nuclear Power Station. J. Guangdong Water Resources and Hydropower, 11: 27-29.

19. Kyle P, Davies E G R, Dooley J J, et al. (2013) Influence of climate change mitigation technology on global demands of water for electricity generation. J. International Journal of Greenhouse Gas Control, 13: 112-123.

20. He Y, Ji C M, Shi P. (2015) Calculation Analysis and Discussion of Blue Water Footprint for Hydropower Research. J. Water Resources and Power, 33(2): 37-41.

21. Singh S, Kumar A, Ali B. (2011) Integration of energy and water consumption factors for biomass conversion pathways. J. Biofuels, Bioproducts and Biorefining, 5(4): 399-409.

22. Liao S K, Wang X Y, Zhu L Z, et al. (2013) Study on water consumption in solar thermal power generation system. J. Ningxia Electric Power, 1: 39-44.

23. Jacobson M Z. (2009) Review of solutions to global warming, air pollution, and energy security. J. Energy \& Environmental Science, 2(2): 148-173.

24. Li X, Feng K, Siu Y L, et al. (2012) Energy-water nexus of wind power in China: the balancing act between $\mathrm{CO}^{2}$ emissions and water consumption. J. Energy Policy, 45: 440-448.

25. National Bureau of Statistics. (2018) China Energy Statistical Yearbook 2017. China Statistics Press, Beijing.

26. China Electricity Council. (2018) Statistics Compilation of China's Electric Power Industry (2017). 